\title{
Pengambilan Harta Wakaf Perspektif Hukum Islam dan Undang-Undang No 41 Tahun 2004 (Studi Kasus di Desa Karang Anyar Kec. Jati Agung Kab. Lam-Sel Tahun 2016)
}

\author{
Ahmad Mukhlishin' ${ }^{1}$, Teguh Arifin'2, Muhammad Dimyati ${ }^{3}$ \\ Institut Agama Islam Ma'arif NU (IAIMNU) Metro Lampung \\ E-mail : ${ }^{1}$ ahmadlisin1988@gmail.com, ${ }^{2}$ aansuhendri76@gmail.com, ${ }^{3}$ dimyatim68@gmail.com
}

\begin{abstract}
Waqf is a legal act of waqif to separate and / or surrender some of his property to be used forever or for a certain period in accordance with his interests for the purposes of worship and / or general welfare according to the Shari'ah. Problems that occur in wakaf property such as that happened in Karang Anyar village, Jati Agung subdistrict, South Lampung regency, there was the event of re-taking of waqf by wakif which initially waqf for boarding school was taken back by wakif for back end to be market. From the background of the above problems can be formulated, the formulation of the problem are: How the law of re-taking of wakaf property by wakif in Karang Anyar Village, Jati Agung District of South Lampung Regency in Perspective of Islamic Law and Law No. 41 of 2004 ?. This research includes field research and quantitative descriptive nature. The results of this study indicate that the law of re-taking of waqf by wakif in Karang Anyar village, Jati Agung sub-district, South Lampung regency, in Islamic law perspective, it is clear that the retrieval of waqf by wakif is permissible, because the Imams of the Madhab believe that the ownership of wakaf property is not on wakif even wakif have no right over the waqf. While in Law no. 41 Year 2004 About Wakaf explained that wakaf property should not be taken back by wakif, but in the case of Taking Back Wakaf Treasures By Wakif In Karang Anyar Village Jati Agung Subdistrict South Lampung Regency wakaf treasures have not been registered to the Official Pledge Deed Achievers (PPAIW) then the law still belongs to the person whose name is written in the land letter.
\end{abstract}

Keywords: Wakaf Treasures, Islamic Law, Law no. 41 of 2004

\section{Abstrak}

Wakaf adalah perbuatan hukum waqif untuk memisahkan dan/atau menyerahkan sebagian harta benda miliknya untuk dimanfaatkan selamanya atau untuk jangka waktu tertentu sesuai dengan kepentingannya guna keperluan ibadah dan/atau kesejahteraan umum menurut syari'ah. Permasalahan yang terjadi pada harta wakaf seperti yang terjadi di Desa Karang Anyar Kecamatan Jati Agung Kabupaten Lampung Selatan, disana tejadi peristiwa pengambilan kembali harta wakaf oleh wakif yang pada awalnya wakaf untuk pondok pesantren diambil kembali oleh wakif untuk di wakafkan kembali untuk dijadikan pasar. Dari latar belakang masalah diatas dapat dirumuskan, rumusan masalah yaitu:Bagaimana hukum pengambilan kembali harta wakaf oleh wakif di Desa Karang Anyar Kecamatan Jati Agung Kabupaten Lampung Selatan dalam Perspektif Hukum Islam dan Undang-Undang No 41 Tahun 2004 ? Penelitian ini termasuk jenis penelitian lapangan (field research) dan bersifat deskriptif kuantitatif, Hasil Penelitian ini menunjukkan bahwa hukum pengambilan kembali harta wakaf oleh wakif didesa Karang Anyar Kecamatan Jati Agung Kabupaten Lampung Selatan dalam Perspektif Hukum Islam sudah jelaslah bahwa pengambilan kembali harta wakaf oleh wakif tidak diperbolehkan, karena para Imam Madzhab berpendapat kepemilikan harta wakaf bukan pada wakif bahkan wakif sudah tidak mempunyai hak atas wakaf itu. Sedangkan dalam UU No. 41 Tahun 2004 Tentang Wakaf dijelaskan bahwa harta wakaf tidak boleh diambil kembali oleh wakif, namun dalam kasus Pengambilan Kembali Harta Wakaf Oleh Wakif Di Desa Karang Anyar Kecamatan Jati Agung Kabupaten Lampung Selatan harta wakaf 
belum di daftarkan ke Pejabat Pembuat Akta Ikrar Wakaf (PPAIW), maka secara hukum tanah tersebut masih milik orang yang namanya tertulis di dalam surat tanah tersebut.

Kata Kunci : Harta Wakaf, Hukum Islam, UU No. 41 Tahun 2004

\section{PENDAHULUAN}

Wakaf adalah perbuatan hukum seorang atau sekelompok orang atau badan hukum yang memisahkan sebagian dari benda miliknya dan melembagakannya untuk selama-lamanya guna kepentingan ibadah atau kepentingan umum lainnya sesuai dengan ajaran Islam. Dalam undang - undang No 41 Tahun 2004 tentang wakaf, mendefinisikan bahwa wakaf adalah perbuatan hukum wâqif untuk memisahkan dan/atau menyerahkan sebagian harta benda miliknya untuk dimanfaatkan selamanya atau untuk jangka waktu tertentu sesuai dengan kepentingannya guna keperluan ibadah dan/atau kesejahteraan umum menurut syariah. $^{1}$

Dalam al-Qur'an telah dijelaskan :

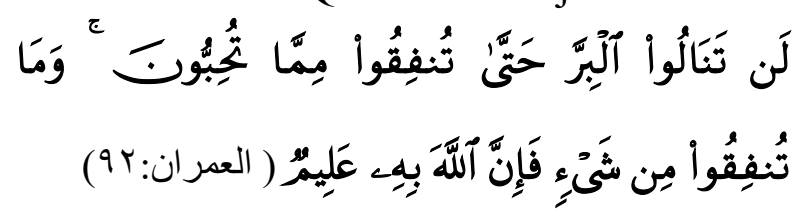

Artinya: "Kamu sekali-kali tidak sampai kepada kebajikan (yang sempurna), sebelum kamu menafkahkan sehahagian harta yang kamu cintai. dan apa saja yang kamu nafkahkan Maka Sesungguhnya Allah mengetahuinya". (QS. Al-'Imran: 92). ${ }^{2}$

Dalam ayat ini terdapat anjuran untuk melakukan infak secara umum terhadap sebagian dari apa yang dimiliki seseorang, dan termasuk ke dalam pengertian umum infak itu adalah wakaf.

\footnotetext{
${ }^{1}$ Miftahul Huda, Mengalirkan Manfaat Wakaf Potret Perkembangan Hukum Wakaf dan Tata Kelola Wakaf di Indonesia, Bekasi: Gramata Publishing, 2015, Undang-Undang no 41 tahun 2004 tentang wakaf pasal 1

${ }^{2}$ Departemen Agama RI, Al-Qur'an dan Terjemahnya, Bandung: Diponegoro, 2005
}

Dasar hukum lainnya adalah hadis Nabi SAW. Yang berbunyi sebagai berikut :

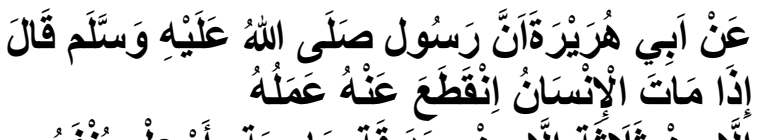

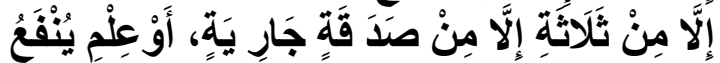

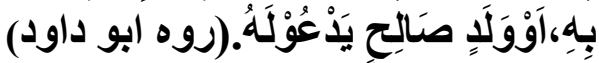

$$
\begin{aligned}
& \text { Artinya: "Jika anak cucu Adam }
\end{aligned}
$$

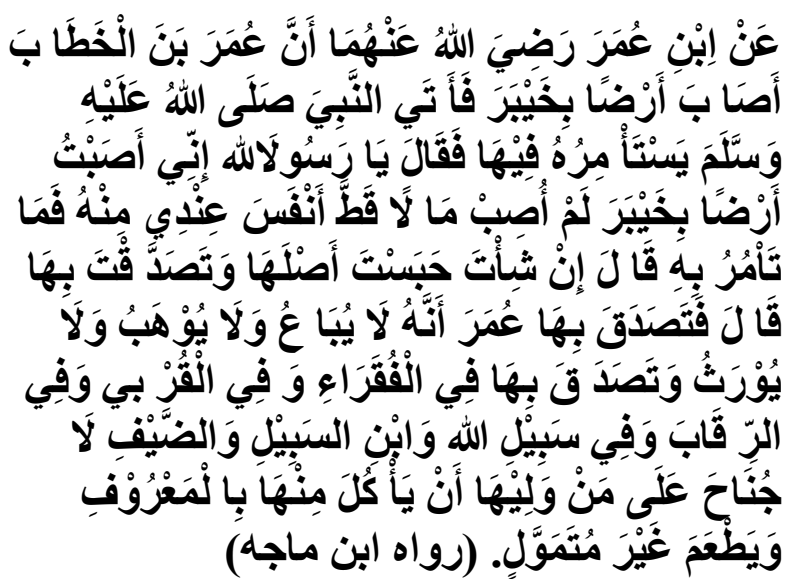

\footnotetext{
3 Abi Daud, Sunan Abi Daud Jilid II, (Beirut: Darul Fikr, 1994), h. 8
} 
untuk orang fakir, kerabat 'Umar, budak, di jalan Allah, dan Ibn Sabil, serta untuk kamu. Orang yang mengelola tanah itu tidak berdosa (bokeh) memanfaatkan hasilnya sekedar untuk dimakan dan memberikan makan teman-teman, bukan untuk mengumpilkan harta (memperkaya diri). (HR. Ibnu Majah)

Hadis tersebut menjelaskan harta wakaf tidak boleh dijual, diwariskan, dan dihibahkan. Berarti harta wakaf tidak merupakan milik perorangan yang bisa dipindah kepemilikannya, tetapi sudah merupakan milik masyarakat (umum). Tidak ada kewenangan pengelola untuk melakukan pemindahan kepemilikan, karena penerima wakaf hanya sebagai pengelola, bukan pemilik salah satu syarat barang yang diperjualbelikan, diwariskan atau dihibahkan adalah milik sendiri. Dalam arti harta wakaf tersebut tidak dapat dialihkan kepemilikannya oleh pengelola.

Pada tanggal 27 Oktober 2004, pemerintah telah mengeluarkan sebuah peraturan baru yaitu Undang-undang No. 41 tahun 2004 tentang Wakaf. Undang-undang ini merupakan Undang-undang pertama yang mengatur wakaf. Salah satu perbedaan undang-undang No. 41 tahun 2004 dengan peraturan perundangan-undangan sebelumnya adalah ruang lingkup substansi yang diaturnya. Undang-undang ini mengatur wakaf dalam lingkup yang lebih luas, tidak terbatas hanya pada wakaf tanah milik. Akan tetapi menjangkau pula pada wakaf Hak Atas Kekayaan Intelaktual seperti yang tertuang dalam Pasal 16 Undang-undang No. 41 tahun 2004 tentang Wakaf yang berbunyi:

(1) Harta benda wakaf terdiri dari:

a. benda tidak bergerak; dan

b. benda bergerak.

(2) Benda tidak bergerak sebagaimana dimaksud pada ayat (1) huruf a meliputi:

\footnotetext{
${ }^{4}$ Ibnu Majah, Sunan Ibnu Majah Jilid II, (Beirut: Darul
} Fikr, tt), h. 801 a. Hak atas tanah sesuai dengan ketentuan peraturan perundangundangan yang berlaku baik yang sudah maupun yang belum terdaftar;

b. Bangunan atau bagian bangunan yang berdiri di atas tanah sebagaimana dimaksud pada huruf a;

c. Tanaman dan benda lain yang berkaitan dengan tanah;

d. Hak milik atas satuan rumah susun sesuai dengan ketentuan peraturan perundang-undangan yang berlaku;

e. Benda tidak bergerak lain sesuai dengan ketentuan syariah dan peraturan perundang-undangan yang berlaku.

(3) Benda bergerak sebagaimana dimaksud pada ayat (1) huruf b adalah harta benda yang tidak bisa habis karena dikonsumsi, meliputi:
a. uang;
b. logam mulia;
c. surat berharga;
d. kendaraan;
e. hak atas kekayaan intelektual;
f. hak sewa; dan
g. benda bergerak lain sesuai dengan ketentuan syariah dan peraturan perundang-undangan yang berlaku. $^{5}$

Dengan adanya Undang-undang No. 41 tahun 2004 tentang Wakaf, tentunya berbeda dari peraturan perundanganundanganan wakaf yang ada sebelumnya. Ruang lingkup wakaf selama ini hanya terbatas hanya pada wakaf tanah milik yang merupakan benda material tidak bergerak. Akan tetapi dengan adanya Undang-undang ini membagai benda wakaf menjangkau terhadap benda tidak bergerak dan benda bergerak.

Wakaf sebagai salah satu lembaga yang berasal dari hukum Islam telah lama dikenal dan hidup dalam masyarakat

${ }^{5}$ Miftahul Huda, Op. Cit , pasal 16 
Indonesia. Namun, praktik dan pengembangan wakaf yang selama ini berjalan di masyarakat masih bersifat sangat konvensional yang pada umumnya hanya ditujukan untuk mendukung sarana dan prasarana ibadah ritual semata, seperti pembangunan tempat ibadah dan pengelolaan pesantren serta tempat pendidikan formal, dalam agama Islam Allah memerintahkan pada manusia, agar memberi nafkah kepada yang butuh, bukan karena Allah tidak mampu memberi secara langsung, tetapi perintah ini adalah untuk kepentingan dan kemaslahatan si pemberi. ${ }^{6}$

selalu $\begin{gathered}\text { Kompleksitas } \\ \text { berkembang }\end{gathered} \begin{gathered}\text { permasalahan yang } \\ \text { seiring }\end{gathered}$ dengan berkembangnya zaman membuat agama Islam meliputi akidah sebagai dasar kepercayaan, akhlak mulia sebagai sarana untuk berkomunikasi dengan sesama manusia yang menentukan baik buruknya perilaku dan ibadah ritual sebagai sarana komunikasi transendensial kepada Allah $\mathrm{SWT}^{7}$, harus menampakkan sifat elastisitas dan fleksibilitasnya guna memberikan yang terbaik serta dapat memberikan kemaslahatan bagi umat manusia. Dalam menjawab permasalahan yang timbul dalam era modern ini, peranan hukum Islam telah nampak dengan adanya perluasan yurisdiksi obyek wakaf.

Pada hakikatnya lembaga wakaf adalah berasal dari hukum Islam, tetapi pada kenyataannya seakan-akan sudah merupakan kesepakatan di kalangan ahli hukum kita untuk memandang masalah wakaf ini sebagai masalah dalam hukum adat di Indonesia. Hal ini dikarenakan sudah meresapnya penerimaan lembaga wakaf ini di dalam

\footnotetext{
${ }^{6}$ Ahmad Mukhlisin dan Nur Hamidah, "Pemanfaatan Harta Wakaf Di Luar Ikrar Wakaf Perspektif Hukum Islam Dan Uu No. 41 Tahun 2004 (Analisis Pemanfaatan Harta Wakaf di Desa Taman Fajar Kecamatan Purbolinggo Lampung Tengah)," Mahkamah: Jurnal Kajian Hukum Islam 2, no. 2 (2017): 220.

7 Aprezo Pardodi Maba, "Bimbingan Dan Konseling Islam Solusi Menjaga Dan Meningkatkan Kesehatan Mental" 3, no. 2 (2017): 10.
}

masyarakat Indonesia dan di anggap sebagai suatu lembaga hukum yang timbul dari hukum adat kebiasaan dalam pergaulam hidup mereka. Bahkan dengan diterimanya lembaga wakaf ini dalam hukum adat merupakan suatu hal yang wajar oleh karena mayoritas penduduk Indonesia beragama Islam.

Seiring berkembangnya lembaga wakaf Indonesia semakin banyak pula para dermawan yang mau mewakafkan hartanya baik untuk pembangunan tempat ibadah seperti masjid dan mushola serta pondok pesantren, pemakaman umum, pasar, dan lain sebagainya. Namun tidak sedikit pula ada yang bermasalah dengan harta yang telah diwakafkan.

Permasalahan yang terjadi pada harta wakaf seperti yang terjadi di Desa Karang Anyar Kecamatan Jati Agung Kabupaten Lampung Selatan, disana tejadi peristiwa pengambilan kembali harta wakaf oleh wakif yang pada awalnya wakaf untuk pondok pesantren diambil kembali oleh wakif untuk di wakafkan kembali untuk dijadikan pasar.

Dari latar belakang diatas maka penulis mengambil penelitian yang berjudul "Pengambilan Harta Wakaf Perspektif Hukum Islam Dan Undang-Undang No 41 Tahun 2004 (Tentang Wakaf Study Kasus Di Desa Karang Anyar Kec. Jati Agung Kab. Lam-Sel Tahun 2016)"

Dari latar belakang masalah diatas dapat dirumuskan, rumusan masalah yaitu: Bagaimana hukum pengambilan kembali harta wakaf oleh wakif ditinjau dari Hukum Islam dan UU No.41 Tahun 2004 (studi kasus di Desa Karang Anyar Kecamatan Jati Agung Kabupaten Lampung Selatan Tahun 2016).

\section{METODE PENELITIAN}

\section{a. Jenis dan Sifat Penelitian}

Penelitian ini termasuk jenis penelitian lapangan (field research), disini peneliti harus terjun ke lapangan, terlibat dengan masyarakat setempat. Terlibat dengan partisipan atau masyarakat turut serta merasakan apa yang mereka rasakan dan juga sekaligus mendapatkan gambaran yang 
lebih komprehensif tentang situasi setempat. Peneliti menemui beberapa warga desa karang anyar yang berkaitan dengan permasalahan wakaf yang sedang diteliti.

Setelah data diperoleh, maka keseluruhan data tersebut dianalisa dengan analisa deskriptif kuantitatif, Penelitian deskriptif adalah penelitian yang dimaksudkan untuk menyelidiki keadaan, kondisi atau hal lain-lain yang sudah disebutkan, yang hasilnya dipaparkan dalam bentuk laporan penelitian, deskriptif dalam penelitian menunjukan tingkat eksplanasiyaitu menanyakan tentang variable mandiri(tidak dihubungkan dan dibandingkan)" 8 .

Sedangkan penelitian ini bersifat kualitatif dikarenakan permasalahan yang diteliti oleh penulis bersifat kompleks karena melibatkan banyak pihak yang berkaitan, penelitian yang digunakan dalam menyusun skripsi ini adalah study lapangan atau penelitian lapangan, yaitu penelitian yang dilakukan dengan cara wawancara dan menelaah buku-buku yang berkenaan dengan Pengambilan Harta Wakaf yang terjadi di Desa Karang Anyar Kecamatan Jati Agung Kabupaten Lampung Selatan Tahun 2016.

Dengan demikian maka penulis mendeskripsikan atau menguraikan datadata yang berkaitan dengan Pengambilan Kembali Harta Wakaf Oleh Wakif Perspektif Hukum Islam dan UndangUndang Nomor 41 Tahun 2004 Tentang Wakaf, kemudian penulis menganalisanya guna untuk mendapatkan suatu pandangan atau kesimpulan berupa kata -kata yang relevan pada saat ini.

\section{b. Sumber data}

Sumber data dalam penelitian ini adalah

a) Data Primer

Data primer adalah sumber data yang langsung memberikan data kepada pengumpul data ${ }^{9}$. Untuk sumber data primer pada penelitian ini yaitu, Undang-Undang Nomor 41 Tahun 2004 dan buku Fiqih Wakaf, yang merupakan sumber yang secara langsung membahas tentang Pengambilan Harta Wakaf Oleh Wakif Perspektif Hukum Islam dan Undang-Undang Nomor 41 Tahun 2004 Tentang Wakaf.

b) Data sekunder

Sumber data sekunder dalam penelitian ini adalah data yang diperoleh dari Al-Qur'an dan hadist, peraturan perundang-undangan, buku fiqh serta buku-buku bacaan yang dapat dijadikan sumber yang relevan dengan penulisan skripsi ini, atau dengan kata lain data sekunder adalah informasi yang telah dikumpulkan pihak lain, jadi peneliti bertindak sebagai pemakai data.

\section{c. Metode Pengumpulan Data}

Dalam penelitaian yang bersifat kuantitatif, dimana pengumpulan datanya melalui penelitian lapangan. "Dalam penelitian kuantitatif, yang menjadi instrumen atau alat penelitian adalah peneliti itu sendiri.berfungsi menetapkan fokus penelitian, memilih informan sebagai sumber data, analisa data, menafsirkan data dan membuat kesimpulan atas temuanya" ${ }^{10}$. Pengumpulan data dilakukan pada natural setting (kondisi alamiah), sumber data primer dan teknik pengumpulan data lebih banyak pada observasi berperan serta (participican observation), wawancara mendalam (indept interview) dan dokumentasi."

\footnotetext{
9 Sugiyono, Metode Penelitian Kuantitatif Kualitatif dan R\&D, Alfabeta, Bandung, 2011, Cet. Ke-12, h. 225

${ }^{10}$ Ibid, h. 222
}

\footnotetext{
8 Sugiyono, statistika untuk Pe
Alfabeta, 2010, Cet. Ke-16, h. 84.
}

Bandung: 
Mencermati uraian di ataş, maka metode pengumpulan yang dipilih oleh penulis dalam penelitian adalah metode observasi dan wawancara mendalam.

\section{1) Metode Wawancara (interview)}

Jenis wawancara yang digunakan oleh penulis adalah wawancara mendalam, yaitu "wawancara yang dilakukan secara informal. Dalam konteks wawancara mendalam "Hubungan pewawancara dengan yang diwawancarai adalah dalam suasana wajar, sedangkan pertanyaan dan bandingannya berjalan seperti pembicara biasa dalam kehidupan seharai-hari.

Wawancara dengan Sumanto selaku nadhir dan juga Kepala Desa Karang Anyar Kecamatan Jati Agung Kabupaten Lampung Selatan bahwa pengambilan kembali tanah itu sudah disetujui oleh masyarakat desa karang anyar dan diperuntukan sebagai bagunan pasar desa.

Penentuan responden sebagai sumber data yang diwawancarai, menggunakan teknik purposive sampling, yaitu: "teknik pengambilan sumber data dengan pertimbangan tertentu. Pertimbangan tertentu ini misalnya orang tersebut dianggap paling tahu tentang apa yang kita harapkan, atau mungkin di sebagai penguasa."

Metode Wawancara penulis gunakan untuk mewawancarai sumber primer dalam penelitian ini, tokoh agama di Desa Karang Anyar Kecamatan Jati Agung, Kabupaten Lampung Selatan, wakif dan nadhir.

\section{2) Dokumentasi}

Dalam penelitian ini dokumentasi digunakan untuk membantu mencari data tentang Study Kasus Pengambilan Harta Wakaf oleh Wakif di Desa Karang Anyar Kecamatan Jati Agung Kabupaten Lampung Selatan, yang berupa tata cara pengambilan kembali harta wakaf, tujuan pengambilan kembali harta Wakaf, lokasi tanah wakaf yang diambil kembali wakif.

\section{d. Metode Pengolahan Data}

Untuk mengolah data yang diperoleh dari penelitian yang dilakukan, langkah-langkah sebagai berikut:

1) Pemeriksaan data (editing), yaitu mengoreksi apakah data yang terkumpul sudah cukup lengkap, sudah benar, dan sudah sesuai atau relevan dengan masalah.

2) Penandaan data (coding), yaitu memberikan catatan atau tanda yang menyatakan jenis sumber data (buku/literature perundang-undangan atau dokumen) atau urutan masalah.

3) Rekonstruksi data (reconstructing), yaitu menyusun ulang data secara teratur, berurutan, logis, sehingga mudah dipahami dan di interprestasikan.

4) Sistematisasi data (systematizing), yaitu menempatkan data menurut kerangka sistematika bahasa berdasarkan urutan masalah.

\section{e. Tehnik Analisa Data}

Selanjutnya analisis dalam penelitian merupakan bagian dalam proses penelitian yang sangat penting, karena dengan analisis inilah data yang akan nampak manfaatnya terutama dalam memecahkan masalah penelitian dan mencapai tujuan akhir penelitian.

Pada dasarnya anilisis adalah kegiatan untuk memanfaatkan data sehingga dapat diperoleh suatu kebenaran atau ketidak benaran dari suatu hipotesa. Data yang telah terkumpul kemudian secara sistematis sesuai dengan sasaran permasalahan, sekaligus dianalisa secara deskriptif kuntitatif yaitu "suatu prosedur penelitian yang menghasilkan data deskriptif berupa kata-kata, tulisan atau lisan dari orang-orang yang berperilaku yang dapat dimengerti. ${ }^{11}$

\footnotetext{
${ }^{11}$ Lexy L. Moelong, Op. Cit., h. 3
} 
Analisis deskriptif kuantitatif ini dipergunakan dengan cara menguraikan dan merinci kalimat-kalimat yang ada sehingga dapat ditarik kesimpulan sebagai jawaban dari permasalahan yang ada dengan menggunakan pendekatan berfikir induktif deduktif.

Bentuk analisis ini dilakukan dengan penjelasan-penjelasan, bukan berupa bentuk angka-angka statistik atau bentuk angka lainnya. Metode yang digunakan dalam menganalisa data ini menggunakan metode deduktif, yaitu: "Suatu penelitian di mana orang berangkat dari pengetahuan yang sifatnya umum, dan bertitik tolak dari pengetahuan yang umum itu kita hendak menilai suatu kejadian yang khusus". ${ }^{2}$

Kaitan dengan penelitian ini, adalah metode dedukdif ini digunakan pada saat penulis mengumpulkan data-data perpustakaan secara umum, dari berbagai buku-buku fiqih, hadist dan sebagainya, tentang suatu konsep, teori ataupun pendapat tentang tinjauan hukum waris Islam pada pelaksanaan tasaluh dalam pembagian harta warisan kemudian diambil kesimpulan secara khusus sampai pada suatu titik temu kebenaran atau kepastian.

Dalam menganalisis data, penulis menggunakan Metode Deduktif yaitu: berangkat dari pengetahuan umum dan bertitik tolak pada pengetahuan umum itu, kita hendak menilai suatu kejadian yang khusus. Terutama penulis menguraikan teori dari fiqih wakaf melalui Hukum wakaf. Kemudian penulis menspesifikasikan lagi kedalam fiqih wakaf terkait dengan hukum pengambilan kembali harta wakaf oleh dalam perspektif hukum Islam dan Undang-Undang, dari situlah kemudian penulis menyimpulkan.

12 Sutrisno Hadi, Metologi Research, Andi, Yogyakarta, 2004, h. 41

\section{KERANGKA TEORI}

\section{Pengertian Wakaf}

Kata "wakaf" dalam bahasa Indonesia berasal dari kata Arab " وقف ", yang berarti menahan atau menghentikan. Kata lain yang sering digunakan sinonim wakaf adalah " yang menurut epistimologi adalah juga bermakna menahan. ${ }^{13}$ Secara terminologi yaitu menahan suatu barang dan memberikan manfaatnya. ${ }^{14}$

Menurut istilah, didefinisikan dengan beragam sesuai dengan perbedaan mazhab yang dianut. Ketika mendefinisikan wakaf, para ulama merujuk kepada imam mazhab, seperti Abu Hanifah, Maliki, Syafi'i dan imam lainnya.

Menurut Abu Hanifah, wakaf adalah menahan suatu benda yang menurut hukum, tetap milik wâqif dalam rangka mempergunakan manfaatnya untuk kebajikan. Menurut mazhab Maliki berpendapat bahwa wakaf itu tidak melepaskan harta yang diwakafkan dari kepemilikan wâqif, namun wakaf tersebut mencegah wâqif melakukan tindakan yang dapat melepaskan kepemilikannya atas harta tersebut kepada yang lain dan wâqif berkewajiban menyedekahkan manfaatnya serta tidak boleh menarik kembali wakafnya. ${ }^{15}$

Mazhab Syafi'i dan Ahmad bin Hambal berpendapat bahwa wakaf adalah melepaskan harta yang diwakafkan dari pemilik wakaf, setelah sempurna prosedur perwakafan. Wâqif tidak boleh melakukan apa saja terhadap harta yang diwakafkan, seperti: perlakuan pemilik dengan cara pemilikannya kepada yang lain, baik dengan tukaran atau tidak.

Definisi lain yang lebih sederhana diberikan oleh Kompilasi Hukum Islam (KHI), wakaf adalah perbutan hukum seorang

\footnotetext{
13 Suhrawardi K. Lubis, Wakaf dan Pemberdayaan Umat, Jakarta: Sinar Grafika, 2010, h. 4

${ }^{14}$ Syaikh Muhammad bin Shalih al-'Usmani, Panduan Wakaf Hibah dan Wasiat Menurut al-Qur'an dan asSunah, Jakarta: Pustaka Imam Asy-Syafi'i Cet. 1, 2008, h. 6

15 Direktorat Pemberdayaan Wakaf Dirjen Bimas Islam, Fiqih Wakaf, h. 2.
} 
atau sekelompok orang atau badan hukum yang memisahkan sebagian dari benda miliknya dan melembagakannya untuk selama-lamanya guna kepentingan ibadah atau kepentingan umum lainnya sesuai dengan ajaran Islam. ${ }^{16}$ Dalam pasal 1 ayat 1 Undang - undang No 41 Tahun 2004 tentang Wakaf, Menyebutkan bahwa wakaf adalah perbuatan hukum waqif untuk memisahkan dan/atau menyerahkan sebagian harta benda miliknya untuk dimanfaatkan selamanya atau untuk jangka waktu tertentu sesuai dengan kepentingannya guna keperluan ibadah dan/atau kesejahteraan umum menurut syari'ah. ${ }^{17}$

Substansi yang terkandung dalam ajaran wakaf adalah adanya semangat penegakan keadilan sosial melalui pendermaan harta untuk kepentingan umum. Walaupun wakaf sebatas amal kebajikan yang bersifat anjuran, tetapi daya dorong untuk menciptakan pemerataan kesejahteraan sangat tinggi. Prinsip dasar wakaf yang bertujuan menciptakan keadilan sosial merupakan implementasi dari sistem ekonomi yang mendorong dan mengakui hak milik individu dan masyarakatsecara seimbang. ${ }^{18}$

Asas kemanfaatan suatu benda menjadi landasan yang paling relevan dengan keberadaan benda itu sendiri. Lebih-lebih ibadah wakaf oleh para ulama dikategorikan sebagai amal ibadah sadaqah jâriyah yang memiliki pahala yang terus mengalir walaupun yang melakukan telah meninggal dunia. Dalam pandangan yang paling sederhanapun, bahwa kontinyuitas pahala yang dimaksud karena terkait dengan aspek kemanfaatan yang diambil secara berkesinambungan oleh pihak kebajikan (masyarakat).

Sebagai obyek wakaf, harta benda

\footnotetext{
${ }^{16}$ Abdurrahman, Kompilasi Hukum Islam, (Jakarta: Akademika Pressindo, 2007) pasal 215 ayat (1).

${ }^{17}$ Undang - undang No 41 Tahun 2004 tentang Wakaf, pasal 1 ayat (1).

18 Direktorat Pemberdayaan Wakaf Dirjen Bimas Islam, Paradigma Baru Wakaf di

Indonesia, (Jakarta: Departemen Agama, 2006), h. 90.
}

yang diwakafkan tersebut bisa dipandang sah apabila memenuhi syarat-syarat sebagai berikut:

a. Benda harus memiliki nilai guna. Wakaf adalah mengambil manfaat benda yang diwakafkan serta mengharap pahala atau keridhaan Allah Swt atas perbuatan tersebut. Tidak sah mewakafkan benda yang tidak boleh diambil manfaatnya, seperti benda memabukkan dan bendabenda haram lainnya.

b. Benda yang diwakafkan benar-benar telah menjadi milik sempurna (al- milk at-tamm) orang yang mewakafkan ketika terjadi akad wakaf. Oleh karenanya, jika seseorang mewakafkan benda yang bukan atau belum menjadi miliknya, walaupun nantinya akan menjadi miliknya, maka hukumnya tidak sah, seperti mewakafkan benda atau sejumlah uang yang masih belum diundi dalam arisan, mewakafkan tanah yang masih dalam sengketa atau jaminan jual beli.

c. Benda yang diwakafkan harus diketahui ketika terjadi akad wakaf. Penentuan benda tersebut bisa ditetapkan dengan jumlahnya atau menyebutkan dengan nisbahnya terhadap benda. Wakaf yang tidak menyebutkan secara jelas terhadap harta yang akan diwakafkan, maka tidak sah hukumnya seperti mewakafkan sebagian tanah.

d. Benda tetap atau benda bergerak yang dibenarkan untuk diwakafkan. ${ }^{19}$

Jadi wakaf adalah ibadah sunah yang dilakukan oleh wakif yang bertujuan untuk penegakan keadilan sosial melalui pendermaan harta untuk kepentingan umum

\section{Dasar Hukum Wakaf}

Para ahli hukum Islam menyebutkan dasar hukum wakaf yang meliputi ayat alQur'an, hadis, ijmak, dan juga ijtihad para ahli hukum Islam Al-Quran sebagai sumber hukum yang pertama memberi petunjuk

\footnotetext{
${ }^{19}$ Ibid., h. 40-42.
} 
secara umum tentang amalan wakaf, sebab amalan wakaf termasuk salah satu yang digolongkan dalam perbuatan baik, sebagaimana firman Allah :

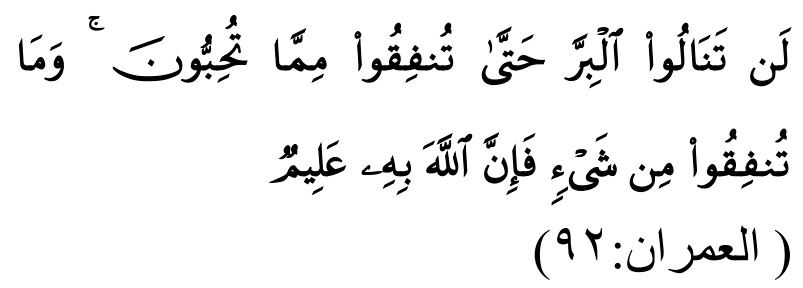

Artinya: "Kamu sekali-kali tidak sampai kepada kebajikan (yang sempurna), sebelum kaтu menafkahkan sehahagian harta yang kamu cintai. dan apa saja yang kamu nafkahkan Maka Sesungguhnya Allah mengetahuinya”. (QS. Al-“Imran: 92) ${ }^{20}$

Dalam ayat ini terdapat anjuran untuk melakukan infak secara umum terhadap sebagian dari apa yang dimiliki seseorang, dan termasuk ke dalam pengertian umum infak itu adalah wakaf.

\section{Rukun Dan Syarat Wakaf}

Dalam perspektif fiqh Islam, untuk adanya wakaf harus di penuhi rukun atau unsur dari wakaf tersebut, yaitu:

a. Adanya orang yang berwakaf (sebagai subjek wakaf) (wakif);

b. Adanya benda yang diwakafkan (sebagai objek wakaf);

c. Adanya penerima wakaf (sebagai subjek wakaf) (nadzir);

d. Adanya 'aqad atau lafaz pernyataan penyerahan wakaf dari tangan wakif kepada orang atau tempat berwakaf (simauquf alaihi). ${ }^{21}$

Dalam pasal 6 Undang-undang Nomor 41 tahun 2004 tentang wakaf, selain unsur rukun tersebut, dimasukan juga sebagai rukun wakaf sebagai berikut:

a. Wakif;

b. Nazhir;

c. Harta benda wakaf;

20 Departemen Agama RI. Al-Qur'an dan Terjemahannya, (Bandung: Diponegoro, 2008)

${ }^{21}$ Rachmadi Usman, Hukum Perwakafan Di Indonesia, (Jakarta: Sinar Grafika, 2009), h. 59 d. Ikrar wakaf;

e. Peruntukan harta benda wakaf;

f. Jangka waktu wakaf. ${ }^{22}$

Dari tiap-tiap unsur rukun wakaf tersebut harus dipenuhi syarat sebagai berikut:

a) Syarat-syarat orang yang mewakafkan (Waqif)

Wâqif adalah orang, atau badan hukum yang mewakafkan benda miliknya. harus mempunyai kecakapan melakukan tabarru' yaitu melepaskan hak milik tanpa imbangan materiil. Artinya mereka telah dewasa (baligh), berakal sehat, tidak dibawah pengampuan, tidak karena terpaksa berbuat dan pemilik benda yang diwakafkan. Sedangkan organisasi dan badan hukum diwakili oleh pengurusnya yang sah menurut hukum dan memenuhi ketentuan organisasi atau badan hukum untuk mewakafkan harta benda miliknya sesuai dengan ketentuan anggaran dasarnya. ${ }^{23}$

b) Syarat-syarat harta yang diwakafkan (Mauquf bih )

Sebagai obyek wakaf, mauqûf bih merupakan hal yang sangat penting untuk perwakafan. Namun, harta yang diwakafkan tersebut bisa dipandang sah apabila memenuhi syarat-syarat, sebagaimana golongan hanafiyah membagi dalam beberapa syarat sebagai berikut:

1) Harta yang diwakafkan itu mesti benda tetap.

2) Harta yang diwakafkan sedang dalam pemilikan wakif ketika ia mewakafkanya.

3) Harta yang diwakafkan sudah dipisahkan dan tidak bercampur baur dengan tanah lainya ${ }^{24}$.

\footnotetext{
${ }^{22}$ Undang - undang No 41 Tahun 2004 tentang Wakaf, pasal 6.

23 Abdurrahman, Kompilasi Hukum Islam, Jakarta: Akademika Pressindo, 2007, pasal 215 dan 217.

${ }^{24}$ Siah Khosi'ah Wakaf dan Hibah Perspektif Ulama Fiqh dan Perkembanganya di Indonesia, Bandung: Pustaka Setia, h. 36
} 
Sedangkan golongan syafi'iyah dan hanabilah mensyaratkan bahwa harta yang akan diwakafkan jelas adanya (kongkrit) dan tidak berada dalam jaminan uutang. Tidak sah wakaf hanya manfaat saja bukan bendanya. Tidak sah wakaf benda yang bermanfaat untuk anjing, babi, binatang buas, burung peliharaan. Tidak sah yang pemanfaatanya tidak berlaku lama, dan wakaf benda yang dapat dipindahkan ${ }^{25}$.

Syarat-syarat yang di jelaskan oleh imam mazhab berbeda satu sama lain hanya ada yang membolehkan barang tidak bergerak dan ada yang berbendapat tidak membolehkanya.

c) Syarat-syarat tujuan/ penerima wakaf

(Mauquf 'alaih)

Mauquf 'alaih tidak boleh bertentangan dengan nilai-nilai ibadah, hal ini sesuai dengan sifat amalan wakaf sebagai salah satu bagian dari ibadah. Selain itu, mauqûf 'alaîh harus jelas apakah untuk kepentingan umum seperti untuk mendirikan masjid atau untuk kepentingan sosial seperti pembangunan sosial atau bahkan untuk kepentingan keluarga sendiri. Apabila ditujukan kepada kelompok orang tertentu, harus disebutkan nama atau sifat mauquf 'alaih secara jelas agar harta benda wakaf segera dapat diterima setelah diikrarkan. Demikian juga diperlukan terhadap organisasi atau badan hukum yang menerima harta benda wakaf. d) Syarat-syarat akad wakaf (Sighat)

Salah satu pembahasan yang sangat luas dalam buku-buku fiqih adalah tentang sighat. Sebelum menjelaskan syaratsyaratnya perlu dijelaskan dulu pengertian akad (sighat).

Ahmad Azhar Basyir mengatakan :

"Akad adalah suatu perikatan antara ijab dan qabul dengan cara yang dibenarkan syara', yang merupakan adanya akibat-akibat hukum pada obyeknya. Ijab adalah pernyataan pihak pertama mengenai isi perikatan yang

${ }^{25}$ Ibid, h. 37 diinginkan sedangkan qabul adalah pernyataan pihak kedua untuk menerimanya". ${ }^{26}$

Syarat akad yaitu perikata ijab (pernyataan pihak pertama) dan qobul (pernyataan pihak kedua untuk menerimanya) dengan cara yang dibenarkan syara' yang merupakan adanya akibat-akibat hukum pada obyeknya.

e) Syarat-syarat pengelola Wakaf (Nazdir)

Pada dasarnya, siapa saja dapat menjadi nazdir asalkan ia tidak terhalang melakukan perbuatan hukum. Akan tetapi, karena tugas nazdir menyangkut harta benda yang manfaatnya harus disampaikan pada pihak yang berhak menerimanya, jabatan nazdir harus diberikan kepada orang yang mampu menjalankan tugas itu. Para imam mazhab sepakat bahwa pentingnya nazdir memenuhi syarat adil dan mampu. Menurut jumhur ulama, maksud"adil" adalah mengerjakan yang diperintah dan menjauhi yang dilarang menurut syari'at Islam. Sedangkan menurut kata"mampu" berarti kekuatan dan kemampuan seseorang mentasharrufkan apa yang dijaga (dikelola) nya. Dalam hal kemampuan ini dituntut sifat taklif, yakni dewasa dan berakal. ${ }^{27}$

Nazdir wakaf adalah orang, organisasi atau badan hukum yang memegang amanat untuk memelihara dan mengurus harta wakaf sebaik-baiknya sesuai dengan wujud dan tujuannya. nazdîr itu adalah perorangan, ada beberapa syarat yang harus dipenuhi, yaitu : warga negara Indonesia, beragama Islam, dewasa, amanah, mampu secara jasmaniah dan rohaniah.

\footnotetext{
${ }^{26}$ Ahmad Azhar Basyir,Op.Cit, h. 65

27 Direktorat Pemberdayaan Wakaf Dirjen Bimas Islam, Paradigma Baru, h. 51.
} 
4. Wakaf dalam Undang-undang No. 41 Tahun 2004 Tentang Wakaf

a) Pengertian Wakaf dalam Undangundang No. 41 Tahun 2004

Dalam pasal 1 ayat 1 Undang undang No 41 Tahun 2004 tentang Wakaf, Menyebutkan bahwa wakaf adalah perbuatan hukum waqif untuk memisahkan dan/atau menyerahkan sebagian harta benda miliknya untuk dimanfaatkan selamanya atau untuk jangka waktu tertentu sesuai dengan kepentingannya guna keperluan ibadah dan/atau kesejahteraan umum menurut syari'ah. ${ }^{28}$

Hukum tidak mengatur kepentingan manusia sebagai perorangan yang berdiri sendiri, terlepas dari manusia yang lain akan tetapi hukum mengatur kepentingan manusia sebagai warga masyarakat. Jadi manusia dalam hubungannnya dengan manusia lain, yang sama-sama terikat dalam ikatan kemasyarakatan. Dengan demikian hak apapun yang diakui oleh hukum, dan diberikan kepada perseorangan atau suatu persekutuan atau kesatuan itu saja, akan tetapi pemberian hak kepadanya itu diberikan dan diakui oleh hukum, oleh karena dengan diberikannya hak tersebut kepada perseorangan, persekutuan atau kesatuan hukum itu, kepentingan seluruh masyarakat akan terpenuhi.

\section{b) Pengaturan Wakaf dalam Undang- undang No. 41 Tahun 2004}

Peraturan perundang-undangan yang selama ini mengatur masalah perwakafan masih tersebar dalam berbagai peraturan perundang-undangan antara lain: Undang-undang No.5 tahun 1960 tentang Undang-undang Pokok Agraria, PP No.28 tahun 1977 Tentang Perwakafan Tanah Milik, Peraturan Menteri Agama RI No.1 Tahun 1978 Tentang Pelaksanaan PP No.28 Tahun 1977, Peraturan Dirjen Bimas Islam depag RI No. Kep/D/75/1978 dan Inpres RI No. 1 Tahun 1991 Tentang

\footnotetext{
${ }^{28}$ Undang - undang No 41 Tahun 2004 tentang Wakaf, pasal 1 ayat (1).
}

Kompilasi Hukum Islam (KHI) dianggap belum memadai dan masih menjadi persoalan yang belum terselesaikan dengan baik, sehingga kemauan kuat dari umat Islam untuk memaksimalkan peran kelembagaan dalam bidang perwakafan masih mengalami kendala-kendala formil. Pada tanggal 27 Oktober 2004, pemerintah mengeluarkan peraturan baru tentang wakaf yaitu Undang-undang No. 41 Tahun 2004 tentang wakaf. Dengan berlakunya undang-undang ini, semua peraturan mengenai perwakafan masih berlaku sepanjang tidak bertentangan dengan dan/atau belum diganti dengan peraturan yang baru berdasarkan undang-undang ini. $^{29}$

Undang-undang wakaf ini merupakan penyempurnaan dari beberapa peraturan perundangan wakaf yang sudah ada dengan menambah hal-hal baru sebagai upaya pemberdayaan wakaf secara produktif dan profesional. Dalam undangundang ini, pentingnya pendaftaran bendabenda wakaf oleh Pejabat Pembuat Akta Ikrar Wakaf (PPAIW) kepada instansi yang berwenang paling lambat 7 (tujuh) hari kerja sejak akta ikrar wakaf ditandatangani. ${ }^{30}$ Sedangkan hal baru yang juga terdapat dalam undang-undang ini dan tidak terdapat dalam peraturan sebelumnya adalah menyangkut dibentuknya badan baru yaitu Badan Wakaf Indonesia (BWI). BWI adalah lembaga independen yang dibentuk oleh pemerintah untuk memajukan dan mengembangkan perwakafan nasional.

Dilihat dari tugas dan wewenang BWI dalam Undang-undang ini nampak bahwa BWI selain mempunyai tanggungjawab untuk mengembangkan

29 Abdul Ghafur Anshori, Hukum dan Praktik Perwakafan, (Yogyakarta: Nuansa Aksara, 2006.) h. 52.

${ }^{30}$ Achmad Djunaidi dan Thobieb Al-Asyhar, Menuju Era Wakaf Produktif, Sebuah UpayaProgresif Untuk Kesejahteraan Umat, cet. ke-3 (Jakarta: Mitra Abadi Press, 2006), h. 93. 
perwakafan di Indonesia, juga mempunyai tugas untuk membina para nazdir. Adapun pengawasan terhadap perwakafan pada umumnya dan nazdir dilakukan oleh pemerintah dibantu badan wakaf atau lembaga wakaf dari negara yang bersangkutan. Di Indonesia misalnya, dalam Peraturan Pemerintah Nomor 42 tahun 2006 tentang Pelaksanaan Undangundang No. 41 Tahun 2004 Tentang Wakaf Pasal 56 ayat (1) disebutkan bahwa pengawasan terhadap perwakafan dilakukan oleh pemerintah dan masyarakat, baik aktif maupun pasif. (2) Pengawasan aktif dilakukan dengan melakukan pemeriksaan langsung terhadap nazdir atas pengelolaan wakaf, sekurang-kurangnya sekali dalam setahun. (3) Pengawasan pasif dilakukan dengan melakukan pengamatan atas berbagai laporan yang disampaikan nazdir berkaitan dengan pengelolaan wakaf; (4) Dalam melaksanakan pengawasan sebagaimana dimaksud pada ayat (1) pemerintah dan masyarakat dapat meminta bantuan jasa akuntan public independen. ${ }^{31}$

Dengan ketentuan di atas diharapkan harta wakaf bisa terlindungi dan pengembangannya tetap terjaga sehingga dapat berfungsi sesuai dengan kehendak wakif.

Dalam menjalankan tugasnya, biaya operasional BWI dibantu oleh pemerintah. Pada akhir masa tugas BWI membuat laporan pertanggung jawaban yang diaudit oleh lembaga audit independen. Dengan dibentuknya BWI, tugas- tugas yang berkaitan dengan wakaf yang selama ini diampu oleh Kantor Urusan Agama (KUA) menjadi kewenangan BWI.

\footnotetext{
${ }^{31}$ Peraturan Pemerintah Nomor 42 tahun 2006 Tentang Pelaksanaan Undang-undang No. 41Tahun 2004 Tentang Wakaf. Pasal 56, ayat (1)
}

\section{Deskripsi Wilayah Penelitian}

a. Profil Desa Karang Anyar Kecamatan Jati Agung Kabupaten Lampung Selatan

Deşa Karang Anyar merupakan salah satu dari 28 deşa di wilayah Kecamatan Jati Agung, yang merupakan kota Kecamatan. Deşa Karang Anyar mempunyai luas wilayah seluas 2.047.69 hektar.

Deşa Karang Anyar mempunyai iklim kemarau dan penghujan. Hal ini mempunya pengaruh langsung terhadap pola tanam yang ada di Deşa Karang Anyar Kecamatan Jati Agung Lampung Selatan.

Secara geografis, Desa Karang Anyar terdiri dari daratan rendah dengan batas-batas wilayah sebagai berikut:

1) Sebelah Utara berbatasan denga Desa Rejomulyo

2) Sebelah Selatan berbatasan dengan Desa Karang Sari

3) Sebelah Timur berbatasan dengan Desa Marga Kaya

4) Sebelah Barat berbatasan dengan Desa Tanjung Laut

b. Visi, Misi, dan Strategi Pembangunan

1) Misi

Desa Karang Anyar memiliki visi "mengentaskan kemiskinan dan meningkatkan taraf hidup masyarakat Desa Karang Anyar"'

2) Misi

Misi yang ingin diwujudkan oleh segenap aparat dan penduduk Desa Karang Anyar adalah sebagai berikut:
a) Meningkatkan pendapatan dan kesejahteraan masyarakat melalui peningkatan produksi pertanian.
b) Mendorong kemandirian dalam berwira usaha
c) Meningkatkan sumberdaya manusia, di bidang ilmu pengetahuan dan teknologi (IPTEK).
d) Meningkatkan etos kerja
e) Meningkatkan kondisi kamtibmas 
3) Strategi Pembangunan

Dalam rangka mewujudkan visi dan misi di atas, maka startegi pembangunan yang diterapkan oleh aparat Desa Karang Anyar adalah sebagai berikut:

a) Menetapkan Karang Anyar sebagai sentra pengembangan hortikultura.

Fokus pengembangan hortikultura yaitu pada komoditi-komoditi sayuran yang memiliki keunggulan komparatif dan diandalkan untuk dapat bersaing dengan daerah lainnya untuk dapat meningkatkan pendapatan masyarakat.

b) Menyusun langkah-langkah operasional pembangunan kecamatan

1) Orientasi pengembangan diarahkan pada peningkatan ekonomi masyarakat

2) Peningkatan kualitas SDM melalui pendidikan

3) Peningkatan peran masyarakat melalui pemberdayaan masyarakat

4) Meningkatkan kualitas hidup masyarakat melalui peduli kesehatan

c) Menetapkan prioritas pengembangan Desa Karang Anyar.

\section{Tabel 1}

Profil Umum Desa Karang Anyar Kecamatan Jati Agung

Kabupaten Lampung Selatan

\begin{tabular}{|l|l|}
\hline Nama Desa & Karang Anyar \\
\hline Kecamatan & Jati Agung \\
\hline Kabupaten & $\begin{array}{l}\text { Lampung } \\
\text { Selatan }\end{array}$ \\
\hline Propinsi & Lampung \\
\hline Luas Wilayah & 2.047.69 ha \\
\hline Mata Pencaharian & \\
\hline - Petani & 271orang \\
Petani Pemilik & 327orang \\
Lahan & 217orang \\
Petani & 47 orang \\
Penggarap & 125orang \\
\hline \multicolumn{2}{|c|}{} \\
\hline
\end{tabular}

\begin{tabular}{|ll|l|}
\hline - & Pengusaha & 46orang \\
& sedang & 2564orang \\
- & Industri Kecil & 51orang \\
- & Buruh Pabrik & 26orang \\
- & Buruh & 17orang \\
& Bangunan & \\
- & Pegawai & \\
& Negri Sipil & \\
- & TNI & \\
- & Pensiunan & \\
& PNS atau TNI & \\
\hline
\end{tabular}

Sumber: Profil Desa Karang Anyar 2016

c. Keadaan Penduduk Desa Karang Anyar

Desa Karang Anyar merupakan Desa yang penduduknya terdiri dari beragama etnis, mulai dari etnis Jawa, Lampung, dan Sunda, dengan jumlah penduduk sebanyak 17.602 Jiwa, yang tersebar di 17 duşun dengan perincian sebagai berikut:

Tabel 2.

Keadaan Penduduk Desa Banding Berdasarkan Dusun

\begin{tabular}{|c|l|c|}
\hline No & \multicolumn{1}{|c|}{ Dusun } & Jumlah Penduduk \\
\hline 1 & Duşun IA & 322 Jiwa \\
\hline 2 & Duşun IB & 313 Jiwa \\
\hline 3 & Duşun IIA & 563 Jiwa \\
\hline 4 & Duşun IIB & 511 Jiwa \\
\hline 5 & Duşun IIIA & 287 Jiwa \\
\hline 6 & Duşun IIIB & 290 Jiwa \\
\hline 7 & Duşun IIIC & 297 Jiwa \\
\hline 8 & Dusun IV A & 346 Jiwa \\
\hline 9 & $\begin{array}{l}\text { Dusun Tega } \\
\text { Lega }\end{array}$ & 490Jiwa \\
\hline 10 & $\begin{array}{l}\text { Dusun Karang } \\
\text { Turi }\end{array}$ & 296 Jiwa \\
\hline 11 & $\begin{array}{l}\text { Dusun } \\
\text { Palputih I }\end{array}$ & 186 Jiwa \\
\hline 12 & $\begin{array}{l}\text { Dusun } \\
\text { Palputih II }\end{array}$ & 291 Jiwa \\
\hline 13 & $\begin{array}{l}\text { Dusun Karang } \\
\text { Mas }\end{array}$ & 265 Jiwa \\
\hline 14 & $\begin{array}{l}\text { Dusun } \\
\text { Permata Asri }\end{array}$ & 346 Jiwa \\
\hline
\end{tabular}




\begin{tabular}{|c|l|c|}
\hline 15 & $\begin{array}{l}\text { Dusun Karang } \\
\text { Indah }\end{array}$ & 417 Jiwa \\
\hline 16 & $\begin{array}{l}\text { Dusun } \\
\text { Priangan }\end{array}$ & 439 Jiwa \\
\hline 17 & $\begin{array}{l}\text { Dusun Karang } \\
\text { Tani }\end{array}$ & 317 Jiwa \\
\hline \multicolumn{2}{|c|}{ Total } & 17.602 \\
\hline
\end{tabular}

Sumber: Profil Desa Karang Anyar 2016

Tabel 3.

Keadaan Penduduk Desa Karang Anyar

Berdasarkan Tingkat Pendidikan

\begin{tabular}{|c|l|c|}
\hline No & $\begin{array}{l}\text { Tingkat } \\
\text { Pendidikan }\end{array}$ & Jumlah \\
\hline 1 & $\begin{array}{l}\text { Belum } \\
\text { SD/Tidak }\end{array}$ & 5211 \\
\hline 2 & SD & 567 \\
\hline 3 & SMP & 5101 \\
\hline 4 & SMA & 2252 \\
\hline 5 & $\begin{array}{l}\text { Tingkat } \\
\text { Akademis }\end{array}$ & 350 \\
\hline 6 & $\begin{array}{l}\text { Tingkat } \\
\text { Perguruan } \\
\text { Tinggi }\end{array}$ & 223 \\
\hline 7 & Buta Huruf & 97 \\
\hline
\end{tabular}

Sumber: Profil Desa Karang Anyar 2016

Gambar 1

Struktur Organisasi Pemerintahan Desa Karang Anyar

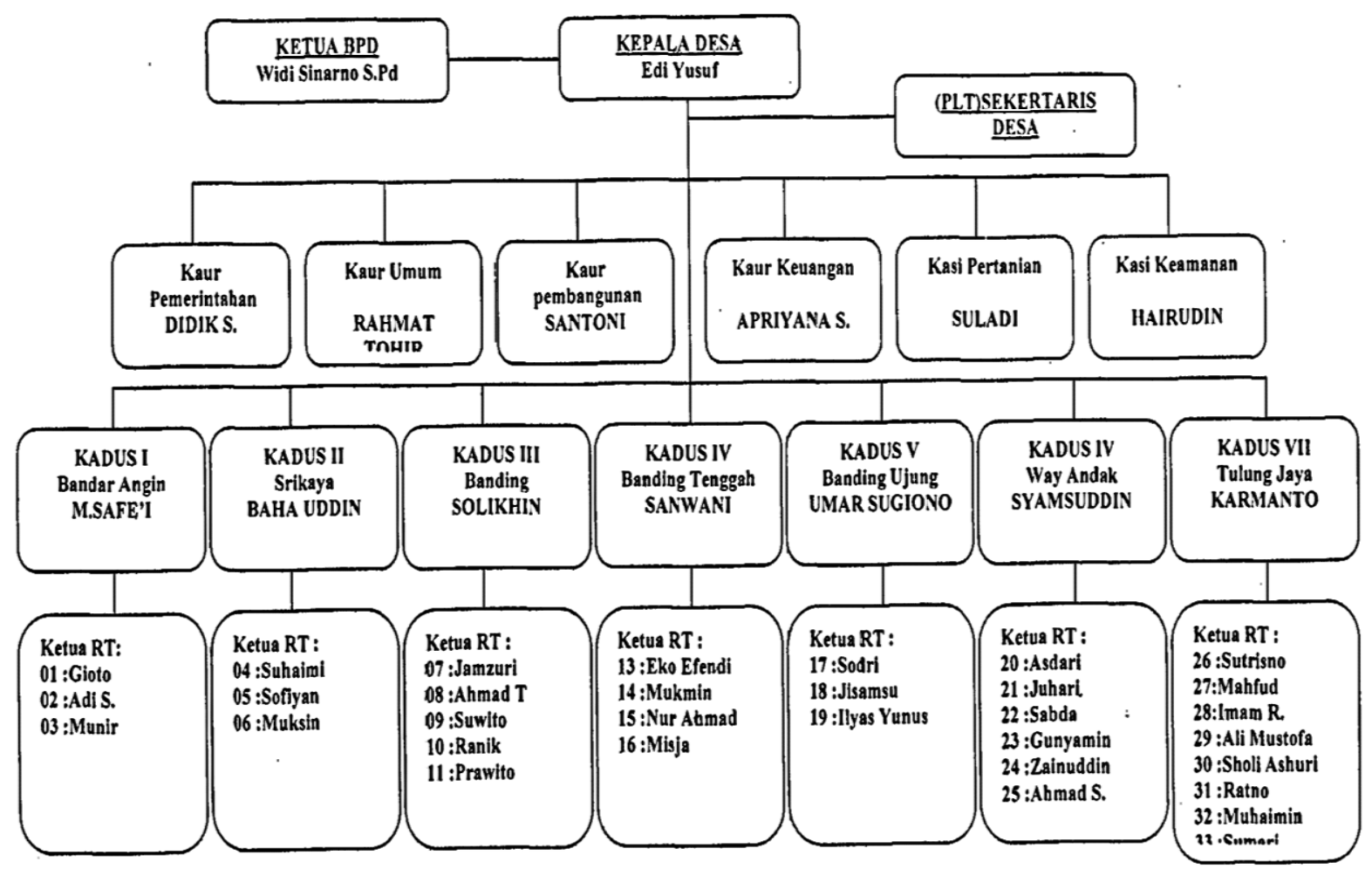


PEMBAHASAN

\section{Kronologi Pengambilan Kembali Harta Wakaf Oleh Wakif di Desa Karang Anyar Kecamatan Jati Agung Kabupaten Lampung Selatan}

Pengambilan kembali harta wakaf oleh wakif yang terjadi di desa karang anyar kabupaten lampung selatan merupakan kejadian yang didasari oleh berbagai macam persoalan antara lain :

a. Tanah wakaf sembilan tahun tidak dipergunakan / dibangun

Perjalanan pengelolaan tanah wakaf yang diminta oleh Bapak Abdul Azis kepada Bapak H M Triono yang dalam perencanaanya akan dibangun yayasan berupa pendidikan Pondok Pesantren ${ }^{32}$ yang tejadi adalah semangat di awal saja, dikarenakan setelah pemberian tanah wakaf, pembangunan yayasan dimulai dengan membangun pondasi sampai waktu Sembilan tahun pembangunan hanya sampai disitu saja.

b. Nadhir mendapatkan tanah wakaf didaerah lain

Seiring berjalanya waktu pengelolaan tanah Wakaf di Desa Karang Anyar Kecamatan Jati Agung Kabupaten Lampung Selatan. Jangka waktu tiga tahun Nadhir pindah ke Desa Maga Kaya karena mendapat tanah wakaf untuk pembangunan yayasan yang lokasinya dianggap lebih strategis untuk pembangunan yayasan ${ }^{33}$.

c. Pemerintah desa membutuhkan lokasi

/ tanah untuk pembangunan pasar

Dari alasan yang disebutkan dalam dua poin diatas maka pemerintah desa meminta tanah / lokasi tersebut kepada Bapak H. M Triono selaku wakif untuk dijadikan pasar desa, karena pasar yang ada di desa karang anyar sudah

\footnotetext{
32 Wawancara dengan Bapak Sumanto, Kepala Desa Karang Anyar pada tangal 21 Februari 2017

33 Sambutan Bapak Abdul Azis pada acara Musyawarah Desa pada hari Senin, tanggal 19 Oktober 2015 selaku Nadhir dan juga selaku Pimpinan Yayasan Darul Ulum, menyampaikan bahwa yayasan darul ulum pindah ke Desa Marga Kaya karena mendapat tanah hibah pada tahun 2008
}

membutuhkan relokasi dan pelebaran , sedangkan tanah yang digunakan untuk pasar saat ini merupakan tanah pribadi yang dimiliki oleh lima orang dari alasan itu pasar tidak akan pernah mendapatkan bantuan apapun dari pemerintah.

Hasil wawancara dengan Bapak Sumanto selaku Kepala Desa Karang Anyar bahwa Pemerintah tidak bisa memberi bantuan apabila tanah pasar bukan milik Negara / pemerintah, sedangkan saat ini tanah yang digunakan untuk pasar adalah tanah milik pribadi, dari alasan tersebut pasar tidak bisa mendapat bantuan namun pasar membutuhkan penambahan lokasi pasar bisa lebih besar dan lebih optimal dalam operasionalnya, dan agar pemerintah desa mendapat hasil dari kegiatan pasar.

\section{Analisis Pelaksanaan Pengambilan Kembali Harta Wakaf Oleh Wakif di Desa Karang Anyar Kecamatan Jati Agung Kabupaten Lampung Selatan}

Pelaksanaan pengambilan kembali harta wakaf oleh wakif yang terjadi di Desa Karang Anyar berdasarkan alasan bahwa tanah tidak dikelola dengan baik dan karena pemerintah desa membutuhkan tanah untuk dijadikan sebagai pasar desa.

Pemaparan tentang pelaksanaan pengambilan kembali harta wakaf oleh wakif yang terjadi di Desa Karang Anyar didasarkan pada hasil wawancara dengan tokoh masyarakat, tokoh agama, dan wakif serta nadhir sebagai berikut:

a. Praktik pengambilan kembali harta wakaf oleh wakif yang terjadi di Desa Karang Anyar Kecamatan Jati Agung Kabupaten Lampung Selatan Menurut Sumanto sebagai nadhir sekaligus kepala desa, pemerintah desa meminta tanah kepada Triono untuk dijadikan sebagai pasar $^{34}$ yaitu meminta tanah wakaf yang tidak di kelola oleh nadhir yang dalam rencana awal akan

\footnotetext{
34 Wawancara dengan Sumanto, nadhir sekaligus kepala desa di Desa Karang Anyar Kecamatan Jati Agung, tanggal 20 februari 2017
} 
dibangun yayasan yang berbentuk pendidikan pondok pesantren.

Lebih lanjut Sumanto menjelaskan tanah yang diminta oleh pemerintah desa adalah lokasi yang strategis dalam pembangunan pasar yang baru, pasar yang benar-benar milik desa karang anyar, pasar yang akan merupakan inkam desa yang bisa membantu dalam kegiatan desa dalam hal pembiayaan karena pasar saat ini bukan milik pemerintah desa atau bukan milik desa melainkan milik pribadi. ${ }^{35}$

Berdasarkan hasil wawancara di atas, diketahui bahwa pengambilan kembali harta wakaf yang telah diberikan oleh wakif berdasarkan permintaan pemerintah desa, yang didasari bahwa tanah tersebut tidak dikelola dengan baik dan bahkan sudah ditinggalkan oleh nadhir karena sudah mendapat tanah wakaf yang lain.

Berbeda dengan penjelasan dari responden di atas, menurut Aef Saifudin ta'mir Masjid Agung Nurul Hikmah Desa Karang Anyar bahwa sangat menyayangkan pengambilan kembali harta wakaf oleh wakif, menurut Aef dalam tata cara pelaksanaan dan pengelolaan tanah wakaf serahkanlah kepada nadhir, apabila wakaf tersebut ingin dialih fungsikan maka bisa dengan pengalihan harta wakaf bukan dengan cara mengambil kembali. ${ }^{36}$

Menurut Ma`ruf, praktik pengambilan kembali harta wakaf oleh wakif yang terjadi di Desa Karang Anyar Kecamatan Jati Agung lebih dilihat sebagai simbol etika dan tata krama dalam masyarakat, ketika pengambilan kembali dan juga pengalihan harta wakaf. Namun demikian menurut Aef, cara pandang masyarakat terhadap pengambilan kembali harta wakaf oleh wakif yang terjadi di Desa Karang Anyar Kecamatan Jati Agung

\footnotetext{
35 Wawancara dengan Sumanto, nadhir sekaligus kepala desa di Desa Karang Anyar Kecamatan Jati Agung, tanggal 20 februari 2017

${ }^{36}$ Wawancara dengan Aef Saifudin, Tokoh Agama di Desa Karang Anyar Kecamatan Jati Agung, Tanggal 21 Februari 2017
}

memang tidak sama, karena dipengaruhi kebutuhan desa dan tidak dikelolanya tanah wakaf dengan maksimal. ${ }^{37}$

b. Tujuan Pengambilan Kembali Harta Wakaf oleh Wakif di Desa Karang Anyar Kecamatan Jati Agung Kabupaten Lampung Selatan

Wakaf adalah sebuah amalan agama islam yang sangat dianjurkan dalam pelaksananya dan mendapatkan pahala yang besar bahkan pahala yang selalu mengalir apabila harta wakaf itu masih digunakan.

Menurut Triono tokoh masyarakat dan juga sebagai wakif yang memberikan tanah bahwa akan lebih bermanfaat apabila tanah itu digunakan. ${ }^{38}$ Berdasarkan surat musyawarah desa yang dilaksanakan pada tanggal 26 januari 2014 di Balai Desa Karang Anyar, Kec. Jati Agung Kab. Lampung Selatan yang dihadiri oleh Kepala Desa, Aparatur Desa, Tokoh Masyarakat, Tokoh Pemuda dan Karang Taruna, menghasilkan kesepakatankesepakatan sebagai berikut:

1) Pembangunan desa karang anyar sebaiknya di tempat yang strategis dan jauh dari jalan raya agar tidak mengganggu kenyamanan berlalu lintas.

2) Dipasang instalasi listik di lapangan, karena lapangan setiap tahun selalu digunakan sebagai tempat sholat idul fiti dan kegiatan desa lainya.

3) Lapangan desa karang anyar supaya dibangun lebih baik lagi, agar lebih bermanfaat bagi masyarakat desa karang anyar. ${ }^{39}$

Lebih lanjut musyawarah yang dilaksanakan menghasilkan kesepakatankesepakatan tentang pembangunan pasar

\footnotetext{
37 Wawancara dengan Aef Saifudin, Tokoh Agama di Desa Karang Anyar Kecamatan Jati Agung, Tanggal 21 Februari 2017

38 Wawancara dengan Triono, Tokoh Masyarakat sekaligus Wakif di Desa Karang Anyar Kecamatan Jati Agung, tanggal 15 Februari 2017

39 Hasil musyaarah desa tantang pasar tanggal 26 januari 2014
} 
diatas, maka dibuatlah musyawarah yang kedua yang bertempat di Balai Desa Karang Anyar Kec. Jati Agung Kab. Lampung Selatan, yang dihadiri oleh perwakilan Kec. Jati Agung, Foerkopimcam Jati Agung, Kepala Desa, Aparatur Desa, Ketua BPD, Ketua RT, Tokoh Agama, Tokoh Masyarakat, Tokoh Pemuda, dan Warga Desa Karang Anyar serta Perwakilan Disperindag Kab. Lampuang Selatan, Dinas PU, sKontraktor Pembangunan Pasar. Yang menghasilkan kesepakatan-kesepakatan sebagai berikut:

1) Menyetujui dan menyepakati pembangunan pasar Desa Karang Anyar yang dibangun ditanah lapangan.

2) Menyetujui dan menyepakati tentang tentang penggeseran lokasi lapangan ketempat yang baru.

3) Kepala Dusun bertanggung jawab penuh atas persetujuan pembangunan pasar dan penggeseran lapangan kepada kepada masyarakat diwilayah dusun masing-masing.

4) Menyetujui dan menyepakati tentang penyelesaian pengurusan terkait Hibah tanah antara Bpk. Ust. Abdul Azis (selaku ketua yayasan ......) dengan pemerintah Desa Karaang Anyar untuk menjadi lapangan yang baru.

5) Apabila selama pelaksanaan pembanguna pasar dan penggeseran lapangan ada sekelompok atau oknum warga desa karang anyar berupaya menghambat dan mengganggu pelaksanaan pembanguna tersebut, maka akan dianggap provokator dan akan kami lapokan kepada pihak yang berwajib sesuai dengan proses hukum yang berlaku. $^{40}$

\footnotetext{
${ }^{40}$ Hasil musyawarah di Balai Desa Karang Anyar Kec. Jati Agung Kab. Lampung Selatan tanggal 08 Oktober 2015
}

Mencermati hasil wawancara dan hasil musyawarah Desa di atas, dapat dikemukakan bahwa tujuan pelaksanaan pengambila kembali harta wakaf di Desa Karang Anyar Kecamatan Jati Agung Kabupaten Lampung Selatan adalah untuk membangun dan menjadikan desa yang lebih baik, dengan cara membangun pasar desa dan menggeser lapangan agar lebih baik lagi.

Setelah data tentang study kasus pengambilan kembali harta wakaf oleh wakif di Desa Karang Anyar Kecamatan Jati Agung Kabupaten Lampung Selatan diperoleh dari hasil wawancara, pada bagian ini dilakukan analisis berdasarkan pandangan hukum Islam dan Undang-Undang No. 41 Tahun 2004 Tentang Wakaf.
c. Pengambilan Kembali Harta Wakaf Dilihat dari Hukum Islam
Harta benda wakaf yang telah diberikan tidak bisa diambil kembali, Miftahul Huda menjelaskan dalam bukunya mengalirkan manfaat wakaf bahwa Iman Nawawi yang bermadzhab syafi'I mendefinisikan wakaf sebagai:

"Penahanan harta yang bisa dimanfaatkan dengan tetap menjaga keutuhan barangnya, terlepas dari camping tangan wakif atau lainya, dan hasilnya disalurkan untuk kebaikan semata-mata dan untuk taqarrub (mendekatkan diri) kepada allah." ${ }^{41}$ Definisi ini mempertegas terlepasnya harta dari kepemilikan wakif, terlepas dari campur tangan wakif atau lainya dan hasilnya disalurkan untuk kebaikan semata-mata untuk mendekatkan diri kepada Allah SWT. ${ }^{42}$

Tidak diragukan sedikit pun bahwa, sebelum sesuatu yang di wakafkan, ia adalah milik orang yang mewakafkan. Sebab wakaf tidak bisa dipandang sah kecuali terhadap barang yang dimiliki. Imam Maliki berpendapat bahwa, esensi atas kepemilikan barang tersebut tetap beada di pemiliknya

\footnotetext{
${ }^{41}$ Miftahul Huda, Mengalirkan Manfaat Wakaf Potret Perkembangan Hukum Wakaf dan Tata Kelola Wakaf di Indonesia, Bekasi: Gramata Publishing, 2015, h. 71 42 Ibid
} 
semula, tapi sekarang dia tidak diperbolehkan menggunakanya lagi. ${ }^{43}$ Menurut Imam Hanafi dan Syafi'i barang yang sudah diwakafkan itu sudah tidak ada pemiliknya lagi. Sedangkan Imam Hambali mengatakan: Barang tersebut berpindah ketangan pihak yang diwakafi. ${ }^{44}$

Mengacu kepada pengertian di atas, sudah jelaslah bahwa pengambilan kembali harta wakaf oleh wakif tidak diperbolehkan, karena para imam madzhab berpendapat kepemilikan harta wakaf bukan pada wakif bahkan wakif sudah tidak mempunyai hak atas wakaf itu.

d. Pengambilan Kembali Harta Wakaf dilihat dari Undang-Undang No. 41 Tahun 2004 Tentang Wakaf

Berdasarkan hasil wawancara dengan beberapa sumber sebelumnya, diketahui bahwa tanah wakaf yang berada di Desa Karang Anyar adalah tanah wakaf yang pengelolanya tidak maksimal karena dalam perjalanan Sembilan tahun tanah wakaf diberikan, belum ada pemecahan surat tanah atau pembuatan akta ikrar wakaf, surat tanah masih utuh atas nama wakif, belum ada pemecahan.

Untuk mendapatkn kekuatan hukum atas tanah yang diwakafkan, maka harus dibuatkan ikrar wakaf dengan suatu akta oleh Kepala KUA sebagai Pejabat Pembuat Akta Ikrar Wakaf. ${ }^{45}$ Dalam Undang-Undang No. 41 Tahun 2004 tentang wakaf disebutkan:

Wakaf dilaksanakan dengan memenuhi unsur wakaf sebgai berikut:
a. Wakif;
b. Nadhir;
c. Harta Benda Wakaf;
d. Ikrar Wakaf;
e. Peruntukan Harta Benda Wakaf;

\footnotetext{
43 Muhammad Jawad Mughniyah,, Fiqih Lima Madzhab, diterjemahkan dari al-fiqh al-madzahib alkhomsah, Jakarta: lentera, 2006, h. 638

${ }^{44}$ Ibid, h 638

45 Adrian Sutedi, Peralihan Hak Atas Tanah dan

Pendaftaranya,Jakarta, Sinar Grafika, Cet-ke 6, h.107
}

f.Jangka Waktu Wakaf. ${ }^{46}$

Dalam pasal 17

(1) Ikrar wakaf dilaksanakan oleh Wakif kepada Nadhir dihadapan PPAIW dengan disaksikan oleh 2 (dua) orang saksi

(2) Ikrar Wakaf sebagai mana dimaksud pada ayat (1) dinyatakan secara lisan dan/atau tulisan serta dituangkan dalam akta ikrar wakaf oleh PPAIW. ${ }^{47}$

Dalam pasal 21

(1) Ikrar wakaf dituangkan dalam akta ikar wakaf.

(2) Akta ikrar wakaf sebagaimana dimaksud pada ayat (1) paling sedikit memuat:
a. Nama dan identitas Wakif;
b. Nama dan identitas Nadhir;
c. Data dan keteragan harta benda Wakaf;
d. Peruntukan Harta Benda Wakaf;
e. Jangka Waktu Wakaf. ${ }^{48}$
Dalam Pasal 9 Peraturan Pemerintah

No. 28 Tahun1997 Tentang Tata Cara Pendaftaran Tanah Mengenai Perwakafan Tanah Milik, pelaksanaan ikrar wakaf, demikian pula pembuatan akta ikrar wakaf diangggap sah, jik dihadiri dan disaksikan oleh sekurang-kurangnya 2 orang saksi, yang disertai dengn surat-surat bukti pemilikan tanah, surat keterangan kepaladesa, suratketerangan pendaftaran tanah.

Dalam semua Undang- Undang dan Peraturan Pemerintah Tentang Wakaf dan Pendaftaran Hak Milik Atas Tanah mensyaratkan adanya ikrar wakaf, karena sangat pentingnya akta tesebut sebagai tanda bukti bahwa sudah di sahkan oleh Negara.

Semua nara sumber yang diwawancarai mengatakan bahwa wakaf memang sudah dilaksanakan, namun pengurusan surat Akta Ikrar Wakaf tidak

\footnotetext{
${ }^{46}$ Undang-Undang No. 41 Tahun 2004 Tentang Wakaf, Pasal 6

${ }^{47}$ Ibid, pasal 17

${ }^{48}$ Ibid, pasal 21
} 
pernah diurus dan dibuat sehingga surat tanah masih milik dan atas nama Wakif, sehingga akibat hukum yang terjadi adalah tanah tersebut masih milik wakif atau masih milik orang yang mempuyai nama dalam surat tanah itu.

Berdasarkan analisa di atas, dapat dikemukakan bahwa pengambilan kembali harta wakaf oleh wakif dalam dalam perspektif islam tidak diperbolehkan secara mutlak, karena harta wakaf itu sudak bukan menjadi hak wakif.

Analisis selanjutnya adalah berdasarkan Undang-Undang No. 41 Tahun 2004 Tentang Wakaf dijelaskan bahwa harta wakaf tidak boleh diambil kembali oleh wakif, namun dalam kasus Pengambilan Kembali Harta Wakaf Oleh Wakif Di Desa Karang Anyar Kecamatan Jati Agung Kabupaten Lampung Selatan harta wakaf belum di daftarkan ke Pejabat Pembuat Akta Ikrar Wakaf (PPAIW), maka secara hukum tanah tersebut masih milik orang yang namanya tertulis di dalam surat tanah tersebut.

\section{PENUTUP}

Berdasarkan data yang terkumpul dalam analisis data, maka dapat disimpulkan hasil penelitian sebagai berikut:

Pengambilan Kembali Harta Wakaf oleh Wakif di Desa Karang Anyar Kecamatan Jati Agung Kabupaten Lampung Selatan Tahun 2016 dalam Perspektif Islam tidak diperbolehkan, karena para imam madzhab berpendapat bahwa kepemilikan harta wakaf bukan pada wakif lagi, bahkan wakif sudah tidak mempunyai hak atas tanah wakaf itu baik tanah wakaf sudah dibuatkan Akta Ikrar Wakaf maupun belum.

Pengambilan Kembali Harta Wakaf oleh Wakif di Desa Karang Anyar Kecamatan Jati Agung Kabupaten Lampung Selatan Tahun 2016 dalam Undang-Undang No. 41 Tahun 2004 Tentang Wakaf, bahwa berdasarkan wawancara dan pengamatan yang dilakukan pada surat tanah, serta pihak Nadhir belum membuat akta ikrar wakaf, maka dalam kekuatan hukum tanah tersebut masih di akui dan milik orang yang mempunyai nama di sertifikat tanah, dan secara hukum belum sah sebagai tanah wakaf.

\section{DAFTAR PUSTAKA}

Abdul Ghafur Anshori, Hukum dan Praktik Perwakafan, Yogyakarta: Nuansa Aksara 2006.

Abdurrahman, Kompilasi Hukum Islam, Jakarta: Akademika Pressindo, 2007.

Abi Daud, Sunan Abi Daud Jilid II, Beirut: Darul Fikr, 1994.

Abi Ishak Ibrahim Ibn Ali Ibn Yusuf AlSyirozi, Al-Muhadzab, Beirut: Darul Fikr, 1993.

Achmad Djunaidi dan Thobieb Al-Asyhar, Menuju Era Wakaf Produktif, Sebuah UpayaProgresif Untuk Kesejahteraan Umat, Cet. ke-3 Jakarta: Mitra Abadi Press, 2006.

Adrian Sutedi, Peralihan Hak Atas Tanah dan Pendaftarannya, Jakarta: Sinar Grafika, 2014.

Agus Pamungkas, Amandemen UndangUndang Dasar 1945, yogyakarta: buku pintar, 2011.

Dalman, Menulis Karya Ilmiah, Ed. 1, Cet. Ke-3 Jakarta: Rajawali Pers, 2003.

Departemen Agama RI. Al-Qur'an dan Terjemahannya, Bandung: Diponegoro, 2008.

Departemen Pendidikaan Nasional, Kamus Besar Bahasa Indonesia, Jakarta: Gramedia Pustaka Utama, 2007.

Direktorat Pemberdayaan Wakaf Dirjen Bimas Islam, Fiqih Wakaf, Jakarta Deprtemen Agama, 2006.

Ibnu Majah, Sunan Ibnu Majah Jilid II, Beirut: Darul Fikr, 1993.

Imam Taqiyuddin Abubakar bin Muhammad Al Husaini, Kifayatul Ahyar Fii Halli Ghayatil Ikhtisar, alih bahasa: Syarifuddin Anwar, Kifatul Ahyar, Surabaya: CV Bina Imam, 2007.

Maba, Aprezo Pardodi. "Bimbingan Dan Konseling Islam Solusi Menjaga Dan 
Meningkatkan Kesehatan Mental" 3, No. 2 (2017): 10.

Miftahul Huda, Mengalirkan Manfaat Wakaf Potret Perkembangan Hukum dan Tata Kelola Wakaf di Indonesia, Bekasi: Gramata Publishing, 2015.

Muhammad bin Ibrahim bin Abdullah AtTuwaijiri, Ensiklopedi Islam AlKamil, Jakarta: Darus Sunnah Press, 2010.

Muhammad Jawad Mughniyah, Fiqih Lima Mazhab diterjemahkan dari kitab alfiqh 'ala al-madzahibal-khamsah, Jakarta: penerbit lentera, 2006.

Mukhlisin, Ahmad, dan Nur Hamidah. "Pemanfaatan Harta Wakaf Di Luar Ikrar Wakaf Perspektif Hukum Islam Dan Uu No. 41 Tahun 2004 (Analisis Pemanfaatan Harta Wakaf di Desa Taman Fajar Kecamatan Purbolinggo Lampung Tengah)." Mahkamah: Jurnal Kajian Hukum Islam 2, no. 2 (2017)

Mundzir Qahar, Manajemen Wakaf Produktif, alih bahasa $\mathrm{H}$. Muhyiddin Mas Rida, Jakarta: KHALIFA, 2005.

Mundzir Qahaf, Al-Waqf al-Islami: Tathawwaruhu, Idaaratuhu wa Tanmiyyatuhu, alih bahasa:Muhyiddin Mas Rida, Manajemen Wakaf Produktif , Jakarta: Khalifah, 2005.

Peraturan Pemerintah Republik Indonesia No. 42 Tahun 2006 Tentang Pelaksanaan Undang-undang No. 41 Tahun 2004 Tentang Wakaf.

Peraturan Pemerintah Republik Indonesia No. 24 Tahun 1997 Tentang Pendaftaran Tanah.

Rachmadi Usman, Hukum Perwakafan Di Indonesia, Jakarta: Sinar Grafika, 2009.

Siah Khosi'ah Wakaf dan Hibah Perspektif Ulama Fiqh dan Perkembanganya di Indonesia, Bandung: Pustaka Setia, 2006.
Sarip Sukandi HDHT, Konsep Wakaf, http://saripedia.wordpress.com/tag/ , diakses 15 Februari 2013

Sayyid Sabiq, Fikih Sunah,Bandung: PT Alma'arif, 1987.

Syaikh Muhammad bin Shalih al-'Usmani, Panduan Wakaf Hibah dan Wasiat Menurut al-Qur'an dan as-Sunah, Cet. 1, Jakarta: Pustaka Imam AsySyafi'i, 2008.

Sugiyono, Metode Penelitian Kuantitatif Kualitatif dan $R \& D$, Cet. Ke-12, Alfabeta, Bandung, 2011.

Sugiyono, Statistik Untuk Penelitian, Bandung: Alfabeta, 2010.

Suharsimi Arikunto, Prosedur Penelitian, Jakarta, Bina Aksara, 1989.

Suhrawardi K. Lubis, Wakaf dan Pemberdayaan Umat, Jakarta: Sinar Grafika, 2010.

Sutrisno Hadi, Metodologi Reseach Jilid, I, Yogyakarta, 1985.

Undang-undang No. 41 Tahun 2004 Tentang Wakaf.

Wahbah Az-Zuhaili, Fiqih Islam Wa adillatuhu, alih bahasa Abdul Hayyie al-Kattani, dkk, Jakarta: Gema Insani, 2011.

Zainuddin Ali, Metode Penelitian Hukum, Jakarta : Sinar Grafika, 2010. 